\title{
Increased metastatic lymph node 64 and CYP17 expression are associated with high stage prostate cancer
}

\author{
A Stigliano ${ }^{1,3}$, O Gandini ${ }^{2}$, L Cerquetti ${ }^{1,3}$, P Gazzaniga $^{2}$, S Misiti ${ }^{1,3}$, S Monti $^{1}$, A Gradilone $^{2}$, P Falasca $^{1}$, \\ M Poggi ${ }^{1}$, E Brunetti ${ }^{3}$, A M Aglianò ${ }^{2}$ and $V$ Toscano ${ }^{1}$ \\ ${ }^{1}$ Endocrinology II Faculty of Medicine, University of Rome 'La Sapienza', Via Cassia, 600-00189 Rome, Italy \\ ${ }^{2}$ Department of Sperimental Medicine and Patology, University of Rome 'La Sapienza', Via di Grottarossa, 1035-00189 Rome, Italy \\ ${ }^{3}$ Research Center AFaR Hospital S. Pietro, Via le Regina Elena, 324-00161 Rome, Italy \\ (Requests for offprints should be addressed to A Stigliano; Email: antonio.stigliano@uniroma1.it)
}

\begin{abstract}
The metastatic lymph node 64 (MLN64), which is localized in the human chromosome 17 , encodes a protein with strong homology with steroidogenic acute regulatory protein. Its overexpression in human breast carcinomas and MLNs led to the hypothesis that this protein could be involved in intraneoplastic steroidogenesis. In the present study, we investigated the expression of MLN64 in prostate cancer, another hormone-dependent tumor, and compared its expression with that of CYP17, the gene encoding for the key enzyme of androgen synthesis. We investigated by RT-PCR the expression of MLN64 and CYP17 in 60 prostatic tumors and compared their expression with the stage of disease and the appearance of relapses in a follow-up of 24 months. We found MLN64 and CYP17 expressed in all samples examined, with significantly higher expression in
\end{abstract}

neoplastic tissues with respect to normal tissues (NTs). Moreover, only in neoplastic but not in NTs, a positive linear correlation was found between MLN64 and CYP17 gene expression. MLN64 and CYP17 expression seems to correlate with high stage, high Gleason score and short relapse-free time. These data, for the first time, demonstrate the presence of MLN64 and CYP17 expression in both normal and neoplastic prostatic tissues. The biological role of MLN64 in human prostate and, particularly, in neoplastic tissue is still unclear. Our findings concerning MLN64 and CYP17 gene expression and their significant positive correlation in human prostate cancer may suggest their possible role in intraneoplastic autonomous steroidogenesis.

Journal of Endocrinology (2007) 194, 55-61

\section{Introduction}

The prostate is an androgen-regulated organ, which has led to longstanding interest in the role of androgens in prostate carcinogenesis (Sandberg 1980). Prostate cancer is one of the most common malignancies among men (Parker et al. 1997). Although evidence of hormonal etiology for prostate cancer is very strong, it is almost entirely circumstantial (Whitmore 1984, Carter \& Coffey 1990). Much of the problem in proving a casual relationship relates to the continued difficulties in the reliable methods for measuring human tissue exposure to endogenous steroid hormones. Androgens have three principal actions on prostatic cells: stimulate proliferation, promote differentiation, and inhibit programmed death or apoptosis (Zhang \& Parker 1985, Montepertit et al. 1986, Rushmere et al. 1987, Coffey 1993, Staack et al. 2003). In normal conditions, a homeostatic equilibrium between proliferation, growth interruption, and apoptosis is present in prostatic tissue. Androgen deprivation determines regression of the gland, inhibiting proliferation and stimulating apoptosis (Coffey 1993, Hellerstedt \& Pienta

2002). Although levels of circulating androgens seem to be in some way related to the emergence of prostate cancer (Nomura \& Kolonel 1991, Miyamoto et al. 2004), it has been reported that progression of the disease cannot be related with the modifications of testosterone serum levels (Carter \& Coffey 1990). This observation led to the hypothesis that in neoplastic tissue, a self-maintaining mechanism may be progressively established.

In 1997, a protein, metastatic lymph node 64 (MLN64), whose gene is localized on the long arm of chromosome 17, was identified in some breast cancer tissues (Tomasetto et al. 1995). This protein is characterized by a C-terminal portion with strong structural homology with steroidogenic acute regulatory protein (StAR), defined StAR homology domain (SHD; Moog-Lutz et al. 1997, Watari et al. 1997). Moreover, it has been demonstrated that MLN64 and StAR have another highly homologous critical region, called the START domain (for StAR-related lipid transfer domains). This START domain contains a hydrophobic tunnel that appears to be capable of binding a single cholesterol molecule in the StAR protein, which is required for the regulation of steroid 
biosynthesis (Stocco 2000, Tsujishita \& Hurley 2000). Thus, as well as StAR protein, MLN64 has a cholesterol-binding domain (Stocco 2000, Tsujishita \& Hurley 2000, Strauss et al. 2003), but unlike StAR protein, the protein is involved in the cholesterol transport from endosome to cytoplasmic acceptors (King et al. 1995, Arakane et al. 1998, Alpy et al. 2001). In this view, MLN64 can enhance steroidogenesis regulating the transfer of cholesterol and its conversion in pregnenolone (Tomasetto et al. 1995, Moog-Lutz et al. 1997, Watari et al. 1997, Lane \& Strauss 2000, Zhang et al. 2002).

MLN64 transcripts have been identified only in breast epithelial malignant tissues and MLNs but not in peritumoral tissues and unimpaired lymph nodes (Moog-Lutz et al. 1997). This observation led us to the hypothesis that some hormonedependent tumors, and among them prostate cancer, may be able to maintain themselves by inducing a specific intratumoral steroidogenesis independently of circulating androgens. The present study was performed in order to evaluate MLN64 gene expression in prostatic cancer tissues and the normal tissues (NTs) surrounding the neoplastic lesion. The first aim of the study was to verify whether MLN64 is also expressed in prostate cancer, another example of a hormonedependent tumor.

The cytochrome P450c17 enzyme functions in the steroid biosynthesis pathway, which mediates both $17 \alpha$-hydroxylase and 17,20-lyase in androgen biosynthesis (Jin-Tang 2006); it catalyzes the conversion of progesterone and pregnenolone into androgens, androstendione and dehydroepiandrosterone respectively, which are precursors of potent androgens (Picado-Leonard \& Miller 2003).

Altered endogenous steroid hormone levels have been reported to be associated with a $\mathrm{T}$ to $\mathrm{C}$ polymorphism in the $5^{\prime}$ promoter region of the CYP17 gene (Spurdle et al. 2002). Thus, the CYP17 genotype may be a biomarker for the onset of breast cancer risk (Feigelson et al. 1997). Furthermore, we investigated in the same samples the expression of CYP17, the gene encoding the key enzyme for androgen formation (Hartmann et al. 2002).

\section{Material and Methods}

\section{Patients}

Sixty patients affected by prostate cancer participated in this study. Patients were aged 59-72 (mean 65.5 \pm 2 ; median 67). Main inclusion criteria were the absence of neoadjuvant chemotherapy, radiation therapy, endocrine therapy, or phytotherapy. The post-surgical stage of each tumor was classified according to the revised tumor-node-metastasis system. We had 22 stage II, 20 stage III, and 18 stage IV. Informed consent was obtained from all patients, and the Ethical Committee approved the study protocol. The characteristics of patients are summarized in Fig. 1.

Follow-up was carried out for 24 months after primary surgery at periodical intervals according to the standard protocols. In this period, 25 out of 60 patients (42\%) developed recurrent disease, 12 with local recurrence and 13 with distant metastases. The mean time of relapse was $11 \cdot 1 \pm 2 \cdot 5$. The median time of relapse was 12 months (range 6-16).

\section{Samples collection}

Tumor tissues were collected during radical prostatectomy, snap-frozen in liquid nitrogen, and immediately stored at $-80{ }^{\circ} \mathrm{C}$ until further analysis. The perineoplastic NTs were isolated under a pathologist's supervision and used as control. In all these samples, the presence of benign prostatic hyperplasia $(\mathrm{BPH})$ or prostatic intraepithelial neoplasia (PIN) was excluded.

\section{$R N A$ extraction and $R T-P C R$}

Total RNA was extracted by Trizol reagent (Gibco-BRL Life Technologies); in order to avoid DNA contamination, all samples were treated after RNA extraction with DNase I (Boehringer Mannheim GmbH). cDNA transcripts were formed from extracted mRNA by reverse transcription using oligo (dT) primers and Moloney murine leukemia virus (MMLV) reverse transcriptase (Promega Corp.). Oligonucleotide primers were designed for PCR amplification of MLN64 gene cDNA, which include the SHD domain, for CYP17 gene, and for the housekeeping gene $\beta$ actin cDNA. Primer sequences were determined from published cDNA sequences for human MLN64, CYP17, and $\beta$ actin (Nakajima-Iijima et al. 1985, Chung et al. 1987, Tomasetto et al. 1995; Table 1).

PCR products were sequenced using the Big Dye Terminator Cycle Sequence Ready Reaction kit on an ABI PRISM 310 Genetic Analyzer (Applied Biosystems, Foster City, CA, USA) in order to confirm the specificity of the amplified products.

As positive controls we used cDNA obtained from ovarian carcinoma cell line (SKOV-3) for MLN64 and from a human adrenal cortical sample for CYP17. Each PCR was run for 32 cycles with a melting temperature of $94{ }^{\circ} \mathrm{C}(30 \mathrm{~s})$, annealing temperature of $60^{\circ} \mathrm{C}(30 \mathrm{~s})$, and extension phase temperature of $72{ }^{\circ} \mathrm{C}(30 \mathrm{~s})$. PCR products were subjected to agarose gel electrophoresis and then visualized by ethidium bromide staining.

We also verified (data not shown) that in our RT-PCR conditions, after 32 amplification cycles; the reactions were in a linear range and not in the plateau and thus were suitable for comparing mRNA amounts.

To correlate the relative expression of cDNA samples, we determined a densitometric comparison of the intensity of the signals by calculating the quotient between the scanning values obtained from MLN64, CYP17, and $\beta$ actin experiments.

Each neoplastic sample was scored according to Gleason (the Gleason score between 3 and 9). 


\section{A}

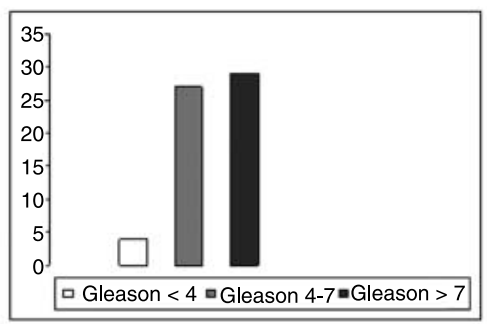

C

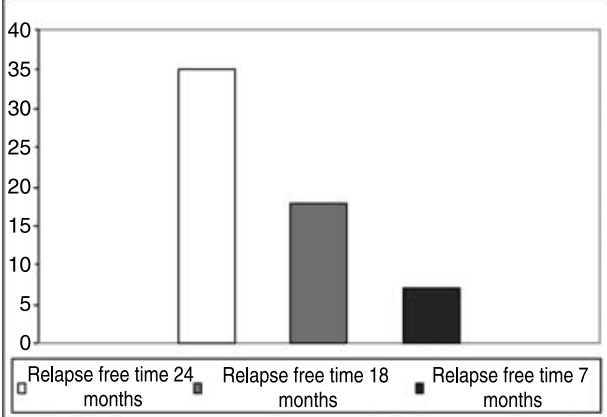

B

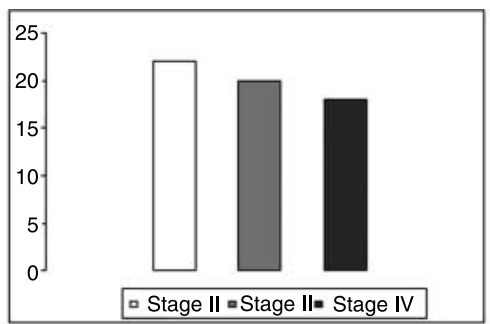

D

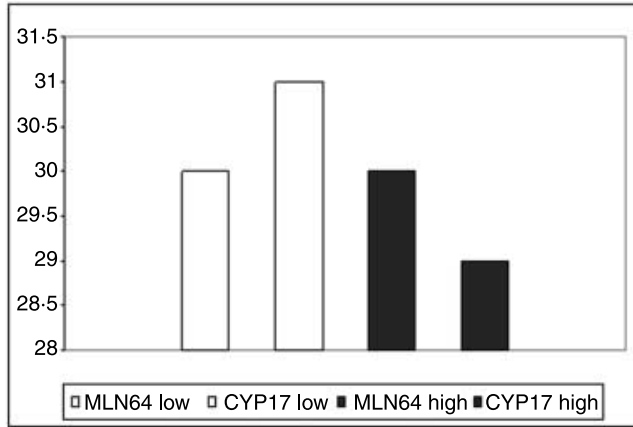

Figure 1 Characteristics of prostate cancer patients. The numbers of the patients subdivided for: (A) Gleason scores; (B) stages of neoplasia; (C) relapse-free time; (D) different expressions of MLN64 and CYP17 in neoplastic tissue.

\section{Protein analysis/tissue preparation}

Frozen tissues (about $400 \mathrm{mg}$ ) from neoplastic and nonneoplastic prostate were sliced and homogenized in lysis buffer $(3 \mathrm{ml} / \mathrm{g}$ of tissue) containing $1 \mathrm{M} \mathrm{NaCl}, 1 \mathrm{M}$ Hepes (pH 7.6), $2 \mathrm{M} \mathrm{MgCl}_{2}, 0 \cdot 1 \mathrm{M} \mathrm{CaCl}_{2}, 0 \cdot 1 \mathrm{M} \mathrm{Na}_{2} \mathrm{PO}_{4}, 0 \cdot 1 \mathrm{M}$ phenylmethylsulphonyl fluoride, and protease inhibitors. After incubation on ice for $30 \mathrm{~min}$, the homogenate was centrifuged at $14000 \mathrm{~g}$ for $15 \mathrm{~min}$ at $4{ }^{\circ} \mathrm{C}$. The supernatant fluid was stored at $-80{ }^{\circ} \mathrm{C}$ until use.

\section{Western analysis}

Protein extracts of $80 \mu \mathrm{g}$ were examined for MLN64 expression. After separation on a $12 \%$ SDS-PAGE, the proteins were then transferred to polyvinylidene fluoride (PVDF) tranfer

Table 1 Primer sequences for PCR of metastatic lymph node 64 (MLN64), CYP17, and $\beta$ actin

\section{Sequences}

\section{PCR primers}

MLN64-F

MLN64-R

CYP17-F

CYP17-R

$\beta$ Actin-F

$\beta$ Actin-R
GCT CAG GAG CGG GAG TAC ATC CGC AGC TCG CTG ATG CGC TGT CGC AGG GGC CCC ATC TAT TCT GTT CGT

TTC AAC TCA GGG TCC CCA TTC ACC AAC TGG GAC GAC ATG GAG CGT GAG GAT CTT CAT GAG GTA GTC membrane and non-specific binding sites were blocked by incubation with $5 \%$ non-fat dry milk in PBS $1 \times 0 \cdot 1 \%$ Tween 20 (PBS-T) for $2 \mathrm{~h}$ at room temperature (RT).

The membrane was incubated overnight at $4{ }^{\circ} \mathrm{C}$ with a $1: 500$ diluted rabbit anti-rat polyclonal antibody (Vinci-Biochem), which cross-reacts with human MLN64. The membrane was then washed thrice for $10 \mathrm{~min}$ in PBS-T. Immunodetection of the primary antibody against MLN64 was carried out after incubation with a 1:10 000 diluted peroxidase conjugate antirabbit anti-IgG secondary antibody (Sigma-Aldrich) for $45 \mathrm{~min}$ at RT and washed for 5 min in PBS-T.

The MLN64 protein band intensity was normalized to the corresponding actin (Sigma-Aldrich) band to allow a quantitative comparison between protein samples. Bands were quantified with an analysis software (Total Lab-Image analysis solution version 2003 non linear dynamics, UK); the integral of the density over a measured area was taken to calculate the amount in each sample, according to the standard values.

\section{Statistical analysis}

Statistical analysis was performed using a computerized system (GraphPad Software Prism 3 and BMDP Inc. San Diego, CA, USA). Paired $t$-test was used to analyze MLN64 and CYP17 values in neoplastic and the corresponding NT.

Fisher's exact probability test was used in order to evaluate the correlation between MLN64 and CYP17 mRNA 


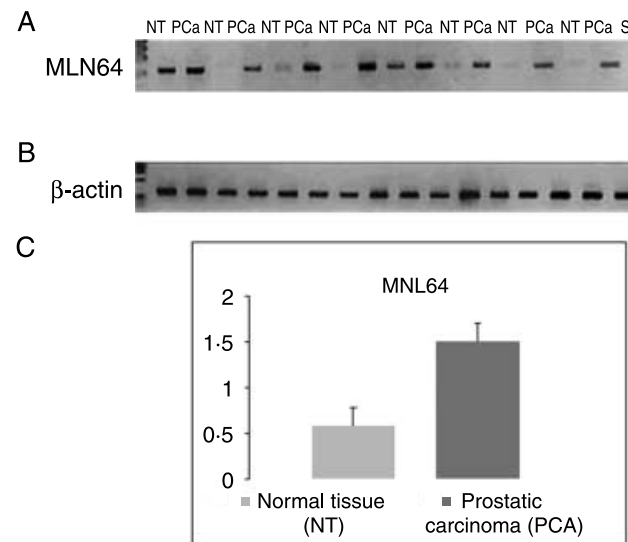

Figure 2 Expression of MLN64 mRNA in prostate carcinoma (PCa) and the corresponding normal tissue (NT). (A) A very high expression of MLN64 mRNA was exhibited by prostate carcinoma when compared with the normal prostate sample. (B) Parallel amplification of $\beta$ actin mRNA served as internal control. (C) Densitometric values of MLN64 mRNA expressed in OD units relative to $\beta$ actin mRNA levels are shown. Bars represent mean values of 60 normal tissues and 60 prostate carcinomas. The statistical analysis was performed by paired $t$-test $(P<0 \cdot 004)$.

expression with clinicopathological variables, specifically the Gleason score and stage of disease. The time of recurrence was calculated from the data of primary surgery; relapse-free time was estimated by Fisher's exact probability test. A value of $P<0 \cdot 005$ was considered statistically significant.
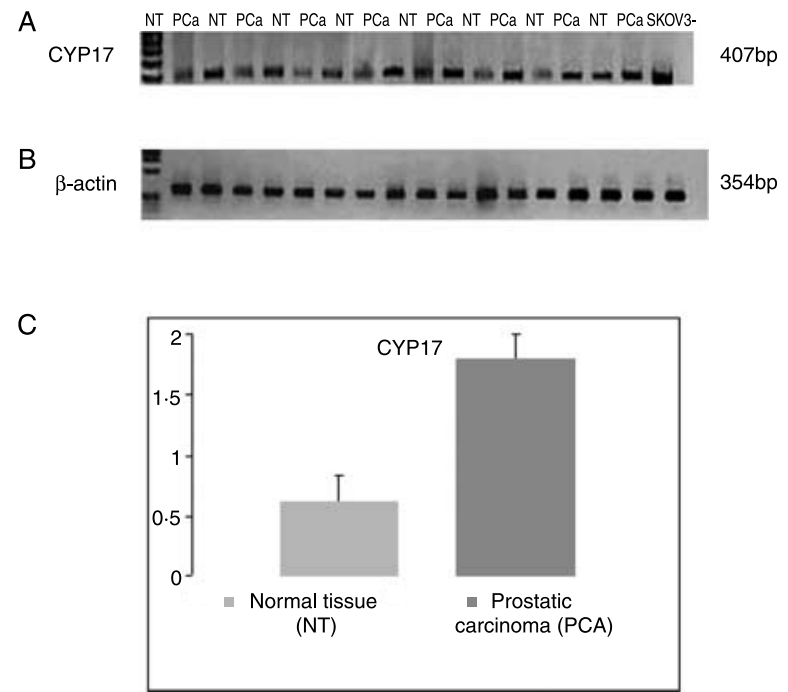

Figure 3 Representative RT-PCR assay showing CYP17 mRNA in different normal and neoplastic tissues. (A) The very high expression of the protein was detected in prostate carcinoma when compared with the normal tissue. (B) $\beta$ actin mRNA expression in prostate carcinoma (PCa) and the corresponding normal tissue (NT) was used as internal control. (C) The results of densitometric analysis of all samples studied are reported. Bars represent mean values of 60 normal tissues and 60 prostate carcinomas. The statistical analysis was performed by paired $t$-test $(P<0 \cdot 002)$.

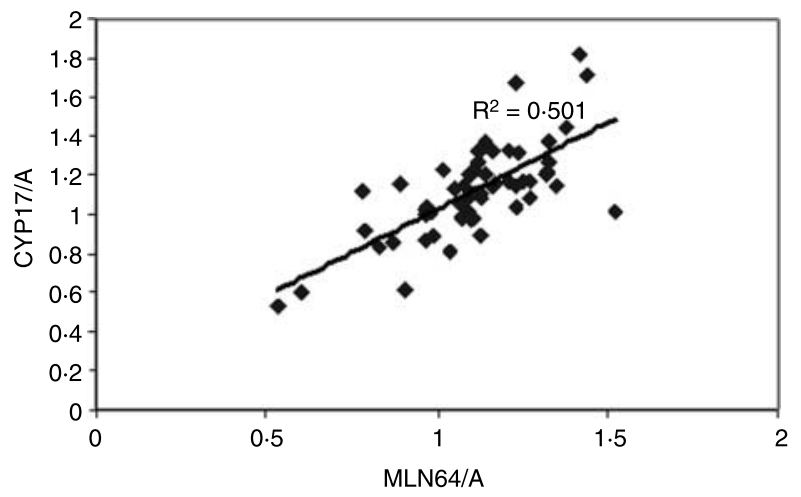

Figure 4 Linear regression analysis between CYP17/ $\beta$ actin and MLN64/ $\beta$ actin ratios in 60 prostate cancer tissues. The expression of CYP17, reported in $y$ axis, showed a linear positive correlation with MLN64 expression, reported in $x$ axis, only in neoplastic tissues $(P<0 \cdot 005)$.

\section{Results}

The mRNA values represent the mean of two different RNA extractions, each one amplified twice by PCR semiquantitative method. All results of MLN64 and CYP17 genes were expressed as a ratio with the $\beta$ actin, the housekeeping gene.

The results obtained show the presence of MLN64 and CYP17 mRNA expression in all samples. Interestingly, neoplastic tissues showed an increased expression of the MLN64 and CYP17 genes when compared with the NTs which was statistically significant $(P<0 \cdot 004$ and $P<0 \cdot 002)$ respectively for MLN64 and CYP17 (Figs 2 and 3). The expression of CYP17 showed a linear positive correlation with MLN64 expression only in neoplastic tissues $(P<0 \cdot 005$; Fig. 4$)$, but not in the normal surrounding tissues. No difference in the expression of $\beta$ actin was found between normal and neoplastic tissues (NT and prostate carcinoma; PCa respectively).

In order to evaluate MLN64 protein expression in PCa, western blot analysis was carried out on SDS-PAGE separation of total protein isolated from all samples. MLN64 was present in prostate homogenates of all patients studied, but its expression was more evident in patients with a Gleason score $>7$ (Fig. 5).

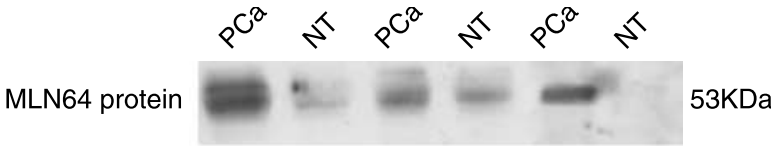

$\beta$ actin

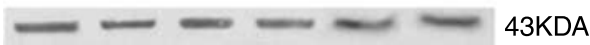

Figure 5 Western blot analysis of total protein extracts ( $80 \mu \mathrm{g} / \mathrm{lane})$ from prostate tissue homogenate. In prostatic carcinomas (PCa), there were high levels of the MLN64 protein when compared with the normal prostate tissue. The Gleason score for all PCa samples was $>7$. 
Table 2 Correlation between metastatic lymph node 64 (MLN64) (a) and CYP17 (b) mRNA expression and clinicopathological features performed by Fisher's exact probability test

\begin{tabular}{|c|c|c|c|}
\hline & $\begin{array}{l}\text { MLN64 low } \\
\text { expression }\end{array}$ & $\begin{array}{r}\text { MLN64 high } \\
\text { expression }\end{array}$ & $P$ value \\
\hline \multicolumn{4}{|l|}{$\begin{array}{l}\text { (A) Clinicopatho- } \\
\text { logical features }\end{array}$} \\
\hline \multicolumn{4}{|l|}{ Stage } \\
\hline II & $21 / 22(95 \%)$ & $1 / 22(5 \%)$ & $<0.005$ \\
\hline III & $7 / 20(35 \%)$ & $13 / 20(65 \%)$ & \\
\hline IV & $2 / 18(11 \%)$ & $16 / 18(89 \%)$ & \\
\hline \multicolumn{4}{|l|}{ Gleason } \\
\hline$<4$ & $4 / 4(100 \%)$ & $0 / 4(0 \%)$ & $<0 \cdot 005$ \\
\hline $4-7$ & 24/27 (89\%) & $3 / 27(11 \%)$ & \\
\hline$>7$ & $2 / 29(7 \%)$ & $27 / 29(93 \%)$ & \\
\hline $\begin{array}{l}\text { (B) Clinicopatho- } \\
\text { logical features }\end{array}$ & $\begin{array}{l}\text { CYP17 low } \\
\text { expression }\end{array}$ & $\begin{array}{l}\text { CYP17 high } \\
\text { expression }\end{array}$ & $P$ value \\
\hline \multicolumn{4}{|l|}{ Stage } \\
\hline II & $22 / 22(100 \%)$ & $0 / 22(0 \%)$ & $<0 \cdot 005$ \\
\hline III & 8/20 (40\%) & $12 / 20(60 \%)$ & \\
\hline IV & $1 / 18(5 \%)$ & $17 / 18(95 \%)$ & \\
\hline \multicolumn{4}{|l|}{ Gleason } \\
\hline$<4$ & 4/4 (100\%) & $0 / 4(0 \%)$ & $<0.005$ \\
\hline $4-7$ & $24 / 27$ (89\%) & $3 / 27(11 \%)$ & \\
\hline$>7$ & $3 / 29(10 \%)$ & $26 / 29(90 \%)$ & \\
\hline
\end{tabular}

This result confirms the data obtained by RT-PCR about MLN64 mRNA expression and disease progression.

When we correlated MLN64 mRNA expression levels with known prognostic factors, we found that high MLN64 mRNA expression significantly correlated with both the clinical stage and the Gleason score. In fact, while in stage II, only $5 \%$ of tumors expressed high levels of MLN64, this percentage reached $65 \%$ in stage III and $89 \%$ in stage IV. A similar correlation was found between higher Gleason score and high MLN64 expression ( $0 \%$ of positive in Gleason $<4$, $11 \%$ in Gleason $4-7$, and $93 \%$ in Gleason $>7$ ).

The same results were obtained for CYP17: $0 \%$ of tumors in stage II expressed high levels of CYP17; this percentage reached $60 \%$ in stage III and 95\% in stage IV. With regard to the Gleason score and high CYP17 expression, we found $0 \%$ of positive in Gleason $<4,11 \%$ in Gleason $4-7$, and $90 \%$ in Gleason $>7$ (Table 2).

When we correlated MLN64 and CYP17 expression with relapse-free time of patients in the first 24 months of followup, we found $8 \%$ of relapses in the group of patients with low MLN64 mRNA expression. On the contrary, in the group of patients with high MLN64 mRNA expression in the tumor, we found relapses (median time 12 months) in $92 \%$ of patients. Data concerning CYP17 are homogeneous to those described for MLN64 (Table 3).

\section{Discussion}

It has been suggested that breast and prostate cancer may be homologous tumors in females and males respectively (LopezOtin \& Diamandis 1998). Both are strongly influenced by steroid hormones, removal of which dramatically reduces the risk of cancer development in both sexes (Eaton et al. 1991, Castoria et al. 2001, Castoria et al. 2004).

Recent studies performed on breast cancer have demonstrated the presence of MLN64, a gene probably involved in the steroidogenesis, in neoplastic tissues (Moog-Lutz et al. 1997, Watari et al. 1997, Alpy et al. 2003).

Our data, for the first time, demonstrates the expression of MLN64 mRNA expression in normal prostatic tissues and its overexpression in prostate cancer, leading to the hypothesis that autonomous steroidogenesis can be present in the gland and particularly in neoplastic tissues. The hypothesis that MLN64 may play a significant physiological role in steroidogenic control was further suggested by a marked expression of the CYP17 enzyme. In fact, the CYP17 gene in the same prostatic samples revealed that it is expressed as well; moreover, only in neoplastic tissues a positive linear correlation has been found between MLN64 and CYP17.

To strengthen our hypothesis, we found that a high MLN64 and CYP17 expression in the tumors positively correlates with the stage of disease and the Gleason score, with higher levels in 13 patients, all in stage IV, with 8-9 Gleason score. All these results, considered together, permit to suppose that in prostate cancer, an autonomous steroidogenesis could be active leading to a local increase of androgen formation. Therefore, we speculate that the increase in MLN64 and CYP17 activity in PCa tissue could induce activation of steroidogenesis by continuous cholesterol transfer into the mitochondria, enhancing the subsequent androgen biosynthesis through the catalytic activity of cytochrome CYP17. This seems to be more active in tumors with higher Gleason score, with respect to more differentiated cancer; in these tumors, an early escape of tumoral cells from hormone therapy is often observed.

It has been demonstrated that some breast tumors express P450sce and 3-hydroxysteroid dehydrogenase potentially giving them the ability to produce steroid hormones (Sasano et al. 1994). To our knowledge, no data is available in the literature concerning the expression of these steroidogenic enzymes in prostate cancer tissue.

Table 3 Correlation between metastatic lymph node 64 (MLN64) and CYP17 mRNA expression and relapses (Fisher's exact probability test)

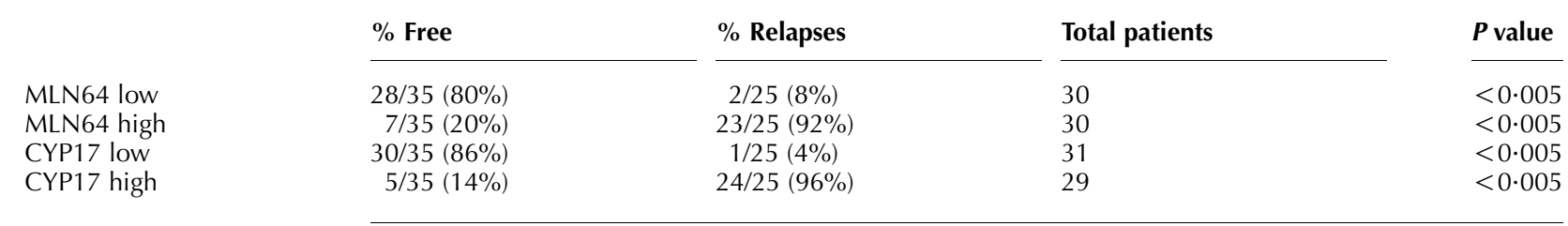


Thus, our data, together with those suggested for breast cancer, may introduce the hypothesis that autonomous androgen formation in prostate cancer may explain the progression of the disease in patients undergoing ablation therapy with gonadotrophin-releasing hormone agonist (Lubrano et al. 1992, Culig et al. 2004) and $5 \alpha$-reductase inhibitors (Steers 2001). The rationale of this therapeutic approach is to suppress testosterone or dihydrotestosterone effects in patients subjected to prostatectomy (Miyamoto et al. 2004). The frequent observation of short relapse-free time in many treated patients (Scher et al. 2004) may suggest the hypothesis that progression of disease in these patients could be due to an alternative independent mechanism of androgen formation.

Here, we report that MLN64 and CYP17 are upregulated and their expressions are closely correlated in PCa. Our data show that MLN64 and CYP17 are increased in higher stages of prostate cancer and the unbalanced expression of each of these genes is associated with poor prognosis of prostate cancer patients.

In conclusion, even if the biological action of MLN64 in prostate cancer still remains unclear, we can hypothesize, due to its strict homology with StAR and its strong correlation with CYP17, that this protein may represent a key for an autonomous steroidogenesis, particularly active in cancerous tissues. Further investigations with larger number of samples are needed in order to clarify the role of MLN64 as a candidate gene in prostate cancer progression. In this context, it would be crucial to establish whether MLN64 may induce prostate cancer progression alone or in cooperation with growth factors, such as EGF, acting on androgen receptor (Lubrano et al. 1992, Hobisch et al. 2004). It is our future aim to investigate whether such cooperation - if existing - may also act in prostatic tumors showing a mutated androgen receptor.

\section{Acknowledgements}

This work was partially financed by research grants (Progetti di Rilevante Interesse Nazionale) from Ministero dell'Università e della Ricerca Scientifica e Tecnologica (MURST) and Università di Roma 'La Sapienza' (Progetti d'Ateneo). The authors declare that there is no conflict of interest that would prejudice the impartiality of this scientific work.

\section{References}

Alpy F, Stoeckel ME, Dierich A, Escola JM, Wendling C, Chenard MP, Vanier MT, Gruenberg J, Tomasetto C \& Rio MC 2001 The steroidogenic acute regulatory protein homolog MLN64, a late endosomal cholesterol-binding protein. Journal of Biological Chemistry 276 4261-4269.

Alpy F, Boulay A, Moog-Lutz C, Andarawewa KL, Degot S, Stoll I, Rio MC \& Tomasetto C 2003 Metastatic lymph nod 64 (MLN64), a gene overexpressed in breast cancers, is regulated by Sp/KLF transcription factors. Oncogene 22 3770-3780.
Arakane F, Kallen CB, Watari H, Foster JA, Sepuri NB, Pain D, Stayrook SE, Lewis M, Gerton GL \& Strauss JF, III 1998 The mechanism of action of steroidogenic acute regulatory protein (StAR). StAR acts on the outside of mitochondria to stimulate steroidogenesis. Journal of Biological Chemistry 273 16339-16345.

Carter HB \& Coffey DS 1990 The prostate: an increasing medical problem. Prostate 16 39-48.

Castoria G, Migliaccio A, Bilancio A, Di Domenico M, De Falco A, Lombardi M, Fiorentino R, Varricchio L, Barone MV \& Auricchio F 2001 PI3-kinase in concert with Src promotes the S-phase entry of oestradiolstimulated MCF-7 cells. EMBO Journal 20 6050-6059.

Castoria G, Lombardi M, Barone MV, Bilancio A, Di Domenico M, De Falco A, Varricchio L, Bottero D, Nanayakkara M, Migliaccio A et al. 2004 Rapid signalling pathway activation by androgens in epithelial and stromal cells. Steroids 69 517-522.

Chung BC, Picado-Leonard J, Haniu M, Bienkowski M, Hall PF, Shively JE \& Miller WL 1987 Cytochrome P450c17 (steroid 17 alpha-hydroxylase/17,20 lyase): cloning of human adrenal and testis cDNAs indicates the same gene is expressed in both tissues. PNAS 84 407-411.

Coffey DS 1993 In The Molecular Biology of the Prostate, pp 28-56. Eds H Lepor \& RK Lawson. Philadelphia: Saunders.

Culig Z, Bartsch G \& Hobisch A 2004 Antiandrogens in prostate cancer endocrine therapy. Current Cancer Drug Targets 4 455-461.

Eaton CL, Davies P, Harper M, France T, Rushmere N \& Griffiths K 1991 Steroids and the prostate. Journal of Steroid Biochemistry and Molecular Biology 40 175-183.

Feigelson HS, Coetzee GA, Kolonel LN, Ross RK \& Henderson BE 1997 A polymorphism in the CYP17 gene increases the risk of breast cancer. Cancer Research 57 1063-1065.

Hartmann RW, Ehmer PB, Haidar S, Hector M, Jose J, Klein CD, Seidel SB, Sergejew TF, Wachall BG, Watcher GA et al. 2002 Inhibition of CYP 17, anew strategy for the treatment of prostate cancer. Archiv der Pharmazie 335 119-128.

Hellerstedt BA \& Pienta KJ 2002 The current state of hormonal therapy for prostate cancer. CA: A Cancer Journal for Clinicians 52 159-179.

Hobisch A, Fiechtl M, Sandahl-Sorensen B, Godoy-Tundindor S, ArtnerDworzak E, Ramoner R, Bartsch G \& Culig Z 2004 Prostate cancer cells generated during intermittent androgen ablation acquire a growth advantage and exhibit changes in epidermal growth factor receptor expression. Prostate 59 401-408.

Jin-Tang D 2006 Prevalent mutations in prostate Cancer. Journal of Cellular Biochemistry 97 433-447.

King SR, Ronen-Fuhrmann T, Timberg R, Clark BJ, Orly J \& Stocco DM 1995 Steroid production after in vitro transcription, translation, and mitochondrial processing of protein products of complementary deoxyribonucleic acid for steroidogenic acute regulatory protein. Endocrinology 136 5165-5176.

Lane KC \& Strauss JF 2000 Steroidogenic acute regulatory protein (StAR) and the intramitochondrial translocation of cholesterol. Biochimica et Biophysica Acta 1529 175-187.

Lopez-Otin C \& Diamandis EP 1998 Breast and prostate cancer: an analysis of common epidemiological, genetic, and biochemical features. Endocrine Reviews 19 365-396.

Lubrano C, Sciarra F, Spera G, Petrangeli E, Toscano V, Rombola N, Palleschi F, Palma E \& Di Silverio F 1992 Immunoreactive EGF in human benign prostatic hyperplasia: relationship with androgen and estrogen receptors. Journal of Steroid Biochemistry and Molecular Biology 41 683-687.

Miyamoto H, Messing EM \& Chang C 2004 Androgen deprivation therapy for prostate cancer: current status and future prospects. Prostate 61 332-353.

Montepertit ML, Lawless KR \& Tenniswood M 1986 Androgen repressed messages in the rat ventral prostate. Prostate 8 25-36.

Moog-Lutz C, Tomasetto C, Regnier CH, Wendling C, Lutz Y, Muller D, Chenard MP, Basset P \& Rio MC 1997 MLN64 exhibits homology with the steroidogenic acute regulatory protein (StAR) and is over-expressed in human breast carcinomas. International Journal of Cancer 71 183-191.

Nakajima-Iijima S, Hamada H, Reddy P \& Kakunaga T 1985 Molecular structure of the human cytoplasmic $B$-actin gene: interspecies homology of sequences in the introns. PNAS $\mathbf{8 2}$ 6133-6137. 
Nomura AMY \& Kolonel LN 1991 Prostate cancer: a current perspective. Epidemiologic Reviews 13 200-227.

Parker SL, Tong T, Bolden S \& Wingo PA 1997 Cancer statistics. CA: A Cancer Journal for Clinicians 47 5-27.

Picado-Leonard J \& Miller WL 2003 Cloning and sequence of the human gene for P450c17 (Steroid 17alpha-hydroxylase/17,20 lyase): similarity with the gene for P450c21. DNA 6 439-448.

Rushmere NK, Parker MG \& Davies P 1987 Androgen receptor binding regions of an androgen-responsive gene. Molecular and Cellular Endocrinology 51 259-265.

Sandberg AA 1980 Endocrine control and physiology of the prostate. Prostate 1 169-184.

Sasano H, Nagura H, Harada N, Goukon Y \& Kimura M 1994 Immunolocalization of aromatase and other steroidogenic enzymes in human breast disorders. Human Pathology 25 530-535.

Scher HI, Buchanan G, Gerald W, Butler LM \& Tilley WD 2004 Targeting the androgen receptor: improving outcomes for castration-resistant prostate cancer. Endocrine Related Cancer 11 459-476.

Spurdle AB, Hopper JL, Chen X, Dite GS, Cui J, McCredie MR, Giles GG, Ellis-Steinborner S, Venter DJ, Newman B et al. 2002 The BRCA2 372 HH genotype is associated with risk of breast cancer in Australian women under age 60 years. Cancer Epidemiology, Biomarkers \& Prevention 11 413-416.

Staack A, Kassis AP, Olshen A, Wang Y, Wu D, Carroll PR, Grossfeld GD, Cunha GR \& Hayward SW 2003 Quantitation of apoptotic activity following castration in human prostatic tissue in vivo. Prostate 54 212-219.

Steers WD 20015 alpha-reductase activity in the prostate. Urology 58 17-21. Stocco DM 2000 StARTing to understand cholesterol transfer. Nature Structural Biology 7 445-447.
Strauss JF, III, Kishida T, Christenson LK, Fujimoto T \& Hiroi H 2003 START domain proteins and the intracellular trafficking of cholesterol in steroidogenic cells. Molecular and Cellular Endocrinology 28 59-65 (Review). Tomasetto C, Régnier CH, Moog-Lutz C, Mattei MG, Chenard MP, Lidereau R, Basset P \& Rio MC 1995 Identification of four novel human genes amplified and over-expressed in breast carcinoma and localized to the q11-q21.3 region of chromosome 17. Genomics 28 367-376.

Tsujishita Y \& Hurley JH 2000 Structure and lipid transport mechanism of a StAR-related domain. Nature Structural Biology 7 408-414.

Watari H, Arakane F, Moog-Lutz C, Kallen CB, Tomasetto C, Gerton GL, Rio MC, Baker ME \& Strauss JF, III 1997 MLN64 contains a domain with homology to the steroidogenic acute regulatory protein (StAR) that stimulates steroidogenesis. PNAS 94 8462-8467.

Whitmore WF, Jr 1984 Natural history and staging of prostate carcinoma. Urologic Clinics of North America 11 205-220.

Zhang YL \& Parker MG 1985 Regulation of prostatic steroid binding protein RNAs by testosterone. Molecular and Cellular Endocrinology 43 151-154.

Zhang M, Liu P, Dwyer NK, Christenson LK, Fujimoto T, Martinez F, Comly M, Hanover JA, Blanchette-Mackie EJ \& Strauss JF, III 2002 MLN64 mediates mobilization of lysosomal cholesterol to steroidogenic mithocondria. Journal of Biological Chemistry 277 33300-33310.

Received in final form 10 April 2007
Accepted 26 April 2007

Made available online as an Accepted Preprint

8 May 2007 